\title{
Sociolinguistic Resources in Mbuko Lynn's Chaque Chose En Son Temps
}

\author{
Sikiru Adeyemi OGUNDOKUN \\ Department of Languages and Linguistics, College of Humanities and Culture, Ikire, Osun State University, \\ Osogbo, Nigeria
}

\begin{abstract}
Sociolinguistic treatment of a text, big or small, holds that it is important to relate the study of language to a society because meaning is derived from both the linguistic level and extra-linguistic contexts. This essay analyses how Mbuko Lynn, a Nigerian writer of French expressions, adopts French language in its African local colour or form to display the cultural practices and social values of especially the Hausa people in the play, Chaque Chose En Son Temps, with emphasis on the use of proverbs and code-mixing as elements of literary creation. Through the theoretical framework of Hymes Ethnography of speaking which emphasizes the manipulation of major text-features such as lexical borrowing, lexical adaptation, code-mixing, code switching, transliteration, funny phonological mimicry and other useful sociolinguistic elements, the text is examined. The paper, as its purpose, explains how language usage in a text forms part of the culture of the society which produces the text and by extension, to underscore the fact that the study of a language should be connected to both the linguistic and extra-linguistic realities in an attempt to establish how certain linguistic features can serve to characterize particular social arrangements. The paper concludes that meaning is a product of linguistic factors and extra-linguistic variables.
\end{abstract}

Key words: Society, Culture, Language, Literature, Linguistics and Proverb.

\section{Introduction}

A defective image of the woman dotted African oral and written literature. Sandra Gilbert and Susan Gubar (1979:76) postulate: "To heal herself, however, the woman writer must exercise the sentences which bred her infection in the first place, "she must overtly and covertly free herself of the despair she inhaled from some "wrinkled maker" and she can only do this by revisiting to marker's texts".

In 2001, as a response to this clarion call, Mbuko Lynn added her voice to the rebuilding or the reconstruction of the old order where a woman was seen and treated only as an object to be used, dumped and not to be heard with the publication of Chaque Chose En Son Temps. The story is about a young girl of thirteen who is a victim of ignorance. With a female character as the heroine in person of Zénabou, the playwright is able to demonstrate her feeling and thinking to achieve her aim. Zénabou, the thirteen year old girl was asked to stop her schooling to marry Elhadj Oumar, an illiterate but a very rich business man from a neighboring village. The said Elhadj had three wives already and was as old as Ahmadou, Zénabou's father. The forced marriage of this premature girl came up because the girl's parents had collected five hundred naira from Elhadj Oumar at the expense of their young girl who was bent on going to Whiteman's school.

During delivery of her first child, Zénabou had serious complications because of her tender age. The baby died, her husband and parents abandoned her. She became a laughing stock to her co-wives. However, luck smiled on her by meeting Dr. Mariama, a woman chief medical officer of a big hospital in a city. The woman adopted Zénabou, healed her of the ailment which seemed to be a threat to her life and trained her to become a qualified nurse.

Upon her certification, Zénabou was employed in that hospital where Dr. Mariama worked as the medical officer. Zénabou became useful to herself, other women who had similar problem like her and the society at large.

The play Chaque Chose En Son Temps has five simple acts and thirty-four scenes and it is set in a typical traditional Hausa community called Garouwa shortly after the independence with all the cultural and societal intrigues. The characters without any exception display the typical responsibilities expected of them. Proverbs are the words of native wisdom and premises for philosophical reflections. Proverbs are used to illuminate metaphysical problem of philosophy. They demonstrate social and cultural realities as well as preserve cultural values for the future generations the events of the past and the present. "The mythological system of a people is often their educational system, and children who sit listening to an evening's tale are imbibing traditional knowledge of sixth graders in our modern classrooms. Myth and legends may contain detailed descriptions of sacred ritual, the codified belief or dogma of the religious group accounts of tribal or 
clan origins, movements and conflicts. Proverbs have often been characterized as the distilled wisdom of past generations, and are unmistakably so regarded by a projective system." Bascon, cited by Adeyanju, D. (1997).

Proverbs as a mirror of social life are poetic and require a deep thinking before one can give appropriate interpretation to them. They have some linguistic features which common statements do not have. Hence, the traditional mind was an active thinking consciousness and not a "tabula rasa".

Casting our mind back to the title of this paper, Sociolinguistic Resources in Mbuko Lynn's Chaque Chose En Son Temps, we present proverbs as an aspect of culture which is expressed through a given language.

\section{Theoretical framework}

Sociolinguistics recognizes the need to relate the system and structure of a language to its social functions. Hudson (1996, p.4) defines sociolinguistics as "the study of language in relation to society." In the words of Trudgill (1983, p.33), sociolinguistics is: "that part of linguistic which is concerned with language as a social and cultural phenomenon. It investigates the field of language and society." However, Downes (1998, p.9) is of the opinion that "sociolinguistics is that branch of linguistics which studies just those properties of language and languages which require reference to social including contextual, factors in their explanation."

To Kachiru (1992, p.34) cultural meaning is expressive in the cognitive structure as well as norms of behavior which people utilize when using a language; that this is of interest to sociolinguists.

Hymes' (1964) Ethnography of communication, the sociolinguistic theory which provides the premises on which this paper is based, is strongly concerned with the relationship between language, culture and society. It takes into consideration those sociolinguistic properties which are present in given communities and examines language as a resource which cannot be divorced from its cultural context.

According to Adeyanju (1997, p. 57): “Adequately deals with various aspects of verbal and non-verbal interactions; that is, linguistic, paralinguistic and non-linguistic realms of interaction... On the linguistic aspect of interaction, the theory is interested in what ought not to be said in different sociolinguistic context... It also answers the question of who speaks what language to whom, where, and when".

Language which is a major facet of culture is again a channel by which people's culture is expressed, displayed and, or showcased. Edward B. Taylor (1997) defines culture as "that complex whole which includes knowledge, belief, art, morals, law, custom and any other capabilities and habits acquired by man as a member of society." To Daramola (2005), culture is "that universal and uniquely human phenomenon consisting of patterns of thinking and believing, doing and behaving, making and using that all humankinds learn in growing up as members of a human society."

Hence, we see culture as socially acquired knowledge. The knowledge one has by virtue of being a member of a given community or society. The word knowledge can be viewed to mean knowing how to do something and knowing that something is or not so. According to Halliday (1975), everybody acquires a social identity while acquiring the first language (L1) and within that frame of social identity; that is, personal style or mannerism. Because everybody can also learn a second language (L2) and even a foreign language (FL) with some of its culture/civilization, a bilingual or multilingual person/polyglot is therefore a bicultural, multi or poly-cultural person.

With the application of Ethnography of speaking, a sociolinguistic theory, the language of our playwright, Mbuko Lyn in Chaque Chose En Son Temps will be x-rayed with our search light on striking linguistic, paralinguistic and extra-linguistic colorations to paint a Hausa society shortly after independence.

\section{Analysis}

This section examines how Mbuko Lynn uses French language, a foreign language to many Nigerians, to demonstrate the social stratification, beliefs attitudes, morals and customs of the Hausa people in general in the play, Chaque Chose En Son Temps.

Proverbs are words of wisdom; well-known phrases and statements which give advice, warning or encouragement. Such expressions are generally believed to be true. Apart from the entertainment value or the aesthetic function, through the use of dramatic situations, exciting imagery and actions, proverbs have educational function. People tell stories and use proverbs to teach social values of life. As a major aspect of culture, Mbuko Lynn uses many proverbs in the play, Chaque Chose En Son Temps to reflect the relationship between a society and a particular language in an attempt to sell the culture of the Hausa people to her audience (readers).

The following are some of the proverbs used in the play

First, the title of the story in itself is proverbial; Chaque Chose En Son Temps meaning everything in its own time or there is time for everything. 


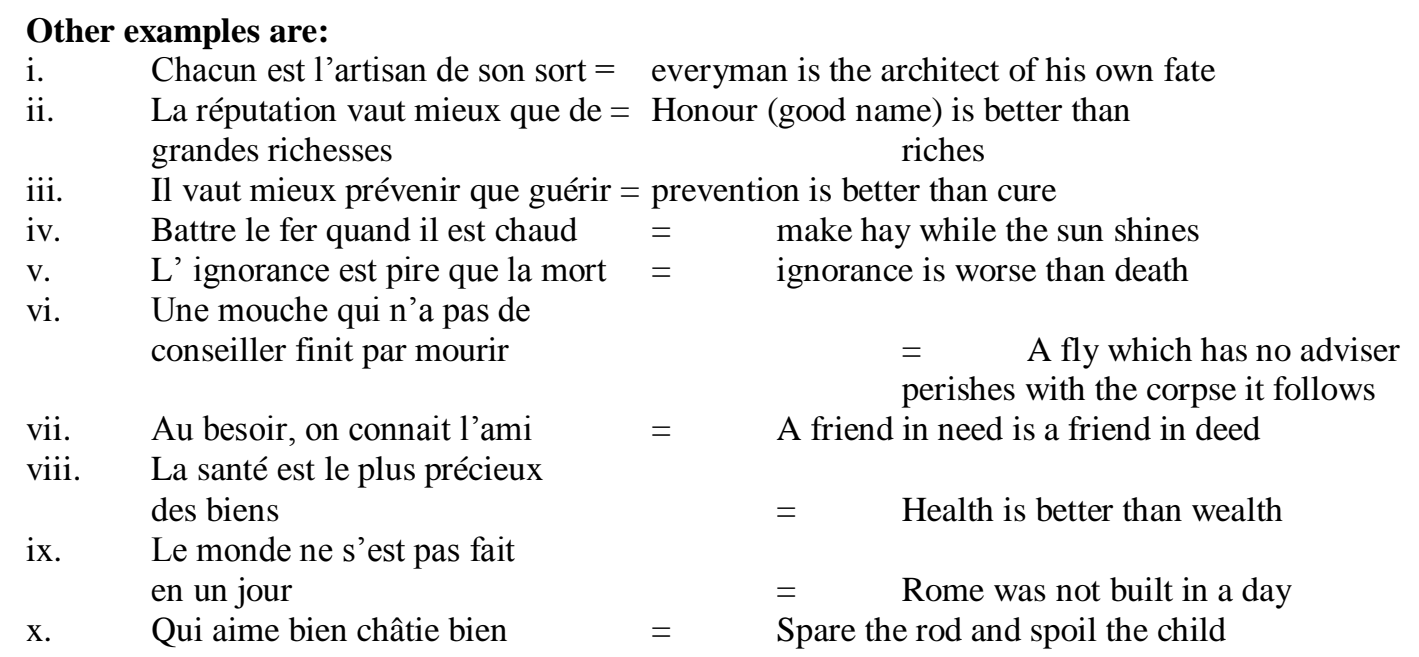

Evaluating the above proverbs, one can note that some proverbs are used to teach the lessons of honesty, kindness, hard work, helpfulness, good faith, obedience and endurance. As a matter of fact, proverbs are used by elders to instruct other elders about specific codes of behavior and to remind listeners or readers of age-old wisdom and truth. Sometimes, proverbs are employed to issue threats or warnings, which the users may not execute later or to direct other people's action where a blunt command might fail or prove offensive. This fact is evident in the selected proverbs, which are paraded above.

Lexical Borrowing and Adaptation

Through this process, writers are able to borrow words from one language to be used in another language. In other words, it is the use of words in a source language to the patter of a target language. This "nativization of a language in a new setting, is often far away from its base (c.f. Akinjobi, 2003). Since the socio-cultural setting of the new language differs from the world-view it needs to present. Most times, translation equivalents are not found and this results in writers loaning, borrowing or adapting lexical items which can express or capture their thoughts as much as possible.

In Chaque Chose En Son Temps therefore, Hausa words like "Foura”, "Kwuli-kwuli", "Mowa”, "Kai”, "pourda", Amarya, "Gafara dai" are used because these words do not have lexical equivalence in French.

The presence of the use of Hausa lexical items and Arabic words in structures which are basically French is evidence that lexical borrowing and adaptation formed significant part of linguistic resources employed by Mbuko Lynn in Chaque Chose En Son Temps. Consider the following sentences:

i. $\quad$ Fatou: $\quad$...Voilà le "foura" que j'ai préparé hier. p.2

Look at the "foura" which I prepared yesterday.

Fatou: $\quad$... Je suis en "pourda",

I am in "pourda" p.3

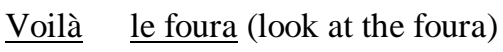

$\mathrm{V} \quad \mathrm{O}$

The word "foura", which is a noun in Hausa, is used here also as a noun to function as an object of this complex sentence:

Violà le foura que j'ai préparé hier.

“que j'ai préparé hier" (which /that I prepared yesterday) is an adjectival/relative clause which qualifies the noun, "foura".

Je suis en pourda $=\mathrm{I}$ am in pourda

The word "pourda" is a noun and is used here in conjunction with the preposition "en" to mean "in pourda" and this makes the phrase function as an adverbial phrase. "Je suis en pourda" is a simple sentence of its own within a compound sentence that reads:

Je suis en pourda, pourtant Mallam ne permet pas que Zénabou aille vendre mes "foura".

I am in pourda, yet my husband does not allow zénabou to go and sell my foura. 
One also noticed the transliteration in the expression:

"Je n'en crois pas mes oreilles "p. 25

I cannot believe my ears

The creative writer is able to express the feeling of the character by resulting in adapting a transliteration to picture the local and societal context of the issue at hand. See another one:

Pour ouvrir les yeux de nos enfants p.20 (to open our children's eyes) instead of saying: pour civilizer nos enfants

Arabic words and phrases such as "Alhamdoullahi", Lahillaha illallah", Allah Akbar", "Inchallah", "Assalah Maléikoum", "Maléikoum Salam", "Walahi”, "Ma chaa-llahu” etc are freely used in the text. Here, the playwright demonstrates not only the milieu of her work but also the contact of her characters with the islamic world and by extension, it is a proof that the writer is also a multi-cultural person. She is an igbo, studies French, works in a Hausa community and all of these have reflected in her creative writing. As student of the society, she even uses Yoruba phrase in the text, "yéyé man” (p. 66).

Code Mixing and Code Switching

Code-mixing is the use of two or more linguistic codes (languages) in a sentence or an utterance while code switching means changing form one language (linguistic code) to another in an utterance or a discourse. These two sister concepts are common features of bilingual and multilingual persons. This practice is possible when the people involved in the communication business can understand the codes which are played on.

In Chaque Chose En Son Temps, this linguistic property is seriously applied. Let us take a look at the conversation between Ahmed and Ahmadou/Boubacar:

Ahmedou: $\quad$ (Salutant les deux) Assalah Maléikoum gens de Garouwa!

Ahmadou:

Boubacar $\}$ (en même temps) Maléikoum Salam!

Ahmadou: Viens t'asseoir ici. On boit quelque chose. C'est le "foura" d'hier. Il est encore frais. (Il offre une calebasse à Ahmed) p.4

Ahmed: $\quad$ (greeting the two) Assalah Maléikoum people of Garouwa!

Ahmadou

Boubacar

(at the same time) Maléikoum Salam!

Ahmadou: $\quad$ Come and sit here. We are drinking something. It is "foura" of yesterday and still fresh. (He offers a cup to Ahmed).

Again, consider this dialogue between El-hadj and Dr. Mariama:

El-hadj: $\quad$ (entre) Na am docteur!

Dr. Mariama: Votre femme a un petit problem, mais tout ira bien, inchallah. P. 97

El-hadj: $\quad$ (enters) Na am, doctor!

Dr. Mariama: Your wife has a little problem, but all will be fine, in challah

The culture of greetings is well established among tribes in Nigeria and among the Hausa people in particular. For instance, the expression:

"Assalah Maléikoum" which means peace is onto you and its response: "Maléikoum Salam meaning peace be onto you too, are common features of greetings in the northern part of Nigeria. Inchallah which means by the grace of God is always heard of; whether as a way of showing their trust in God, the creator of heaven and earth or just as slogan or slang but the truth remains that this element reflects the connectivity between a language and a society.

"Na am" which implies "yes" is a particular word among the Hausa and even Muslims who are non-Hausa as a form of response whenever they are called by another person.

Code-mixing and code-switching therefore demonstrate the culture environment of a text, the belief or the religion the people practice as well as the educational background of the character. It may be indeed necessary to point out that the use of code-mixing and code switching here shows that majority of the characters are illiterates and are not predisposed to western education that can make them speak English Language which is the 
lingua franca/official language in Nigeria not to talk of French language, the code which the playwright has adopted in packaging the text, Chaque Chose En Son Temps.

\section{Haousa Non-verbal Gestures}

Adeyanju (1997, p. 57) claims that: "On the paralinguistic aspects of interaction, The Ethnography of speaking is interested in investigating what kinds of gestures are appropriate for different speech situations. Paralinguistic features such as hand-shake, kneeling, prostrating, a wink of the eye, a nod of the head etc, play a vital role of complementing speech (verbal expressions) These features vary from one speech community to another".

In Act II Scene 3 (p.19), Ahmadou is seen beating his chest proudly to show his confidence that he is not afraid of anything. This gesture is a general attitude of Hausa men to beat their chest in attempt to demonstrate their self-confidence and boldness when ever and where-ever occasions demand. However, in Act II Scene 4, another character, Boubacar is seen wiping his fore-head when he is confronted by director of the new school and his team concerning registration of children in the said new school. This act of robbing or wiping the fore-head indicates a defeat and we can see Boubacar submitting himself to the new order.

Also, in the same Act and Scene, the way Boubacar looks at Dogari with all forms of hatred speaks louder than words. The said look indicates anger and disappointment. In Act II Scene 6 (p.24), Dogari's kneeling down is a mark of respect.

As prostrating oneself is to a typical Yoruba non-verbal gesture of respect, so kneeling down is to a typical Hausa non-verbal communication that pictures respect attached to age, traditional or social status. When the village head called Dogari, we saw him kneel down as a mark of respect before he added the phrase: "Rankai dédé (p. 24).

\section{Phonetic Mimicry}

As used in this paper, it showcases the linguistic interference which can be noticed when majority of Hausa people use a particular sound instead of another particular sound. This is the effect of the native language (mother's tongue) on the second or foreign language. This linguistic feature is mimicry because it shows a socio-cultural setting. For example, Vesicio-Vaginal Fistula, VVF is pronounced as "B.B.Ep". It is a common feature to see a Hausa-man calling "PPL" as $\boldsymbol{F F L}$ OR "PDP" as $\boldsymbol{F D F}$ and so on. It is nothing but language/linguistic interference.

El-hadj: “La B. B. Ep"? Qu'est-ce que c'est que ça? (p.67)

B.B. Ep? What does that mean?

Ahmadou:

“B.B.Ep". C’est quoi ça? (p.77)

B.B.Ep? What is it?

Also, the manner at which the expression yèyé man is articulated shows a degree of phonetic mimicry. A native Yoruba man or woman will say; yèyé man and not yéyé man as it is used in page 66 of the text under review.

From the above analysis, the understanding of some context elements paves way for a better digestion of the message content of a given text. The preoccupation of Mbuko Lynn in Chaque Chose En Son Temps is feminism. It is obvious that feminism has gained a strong acceptance in the continent of Africa, particularly among the long abused African women, and their male sympathizers. However, the extreme radical tendencies which the concept acquired in the West have been handled with much care of moderation as required in Africa. Hence, African feminists draw a line of distinction between their own tolerant brand and the die-hard feminism by projecting a new concept of womanism. Womanism recognizes the needs of the black women are not totally the same as those of the white women, although, it is affirmed that the African woman has gone through series of oppression under the male dominated system.

The womanist holds that man and woman have supportive/complementary roles and that neither of them can survive alone. Bâ, a Senegalese female writer believes there could not be any self-fulfillment outside the "couple" situation. A womanist goes beyond the husband and wife matter. Ousmane and Bâ kick against the abandonment of children. They want children to be trained and educated. However, the meeting point of feminism and womanism is in the area of political marginalization with respect to women. Politics is strongly interwoven with religion, traditional laws and culture, this is evidently defined by popular religious as demonstrated in the Holy Bible and the Glorious Qu'ran and our traditional religion. Political issues are also connected with society and economic matters.

Womanism as a movement, celebrates woman strength as a pillar, the strength that brings black-men to recognize and compromise for harmonious co-existence of both sexes. Womanism is a peculiar culture which reminds men, with outstanding indices that without women's full engagement and involvement in the system; politically, socially, economically, culturally and religiously, man is incomplete in action as well as in 
achievement and this is the central message of Ousmane in majority of his artifacts. This confirms the popular adage: "Behind every successful man, there is a woman".

A genuine African feminism should recognize a common struggle with African men for the removal of the yokes of foreign denomination and European/American exploitation (Davies and Graves, 1986). This is not confrontational to African men; rather it paves way for them to be aware of various salient facets of women's subjugation which are not the same as the popular oppression of all African peoples. "Stiwa", Social Transformation including women of Africa is what we want in Africa. It is not about warring with the men, the reversal of role, or doing to men whatever women think that men have been doing for centuries, but it is trying to build a harmonious society. The transformation of African society is the responsibility of both men and women and it is also in their interest (Omolara Ogundipe Leslie, 1994).

Traditionally in Africa, the image of a woman is that of one who quietly accepts her responsibilities and shares blames with respect. The miserable condition of women in Henri Lopes' La Nouvelle Romance shows the typical picture of African women in real life and in the man-made imaginary world of fictional narratives. "It is Sunday evening; Sunday, a day of feasting and rejoicing, a day of rest from daily duties. But she is in the yard pounding cassava leaves. The married woman is faded the next day after the wedding. She no more has that smile on her face and that quick wit which fascinated the young boys of the village. She is simply a cook, a woman on forced labor..." (Lopes 1976:14). With this statement, Lopes is making it obvious that African women's problems are seriously, the creation of male chauvinism. Hence, feminism should play a significant role to redress and reconstruct the ugly trend.

Mbuko Lynn's Chaque Chose En Son Temps is chosen as our tool to examine the identified problem in Nigeria and in Africa by extension. The choice of this text cannot be divorced from the fact that the preoccupation of Mbuko Lynn in Chaque Chose En Son Temps is the condemnation of forceful premature marriage of female children, which is a strong indication that their education does not really matter. Our choice of Chaque Chose En Son Temps is also guided by the fact that the story is set in Northern Nigeria where Islam takes the central stage as an established accepted religion. The religion permits men to marry up to four wives (Qu'ran 4:3), obliges women to cover their heads, confines married women to family compound and regulates to an extreme level the mixing up of men and women (Qu'ran 24:31 and 33:59-60).

Apart from unacceptable restrictions imposed on women through religious injunctions, African culture itself is a thorn on the flesh of women. An ugly social norm wide spread in Africa is the parental intrusion into marriages of their children. The parents, often motivated by interests contrary to those of their young ones, drag their children away from genuine love and sacrifice their happiness on the altar of greed and social stratification, ethnicity, political difference and local taboos. In Nigeria and Cameroon for instance, girls are especially prevented from having their ideal choice in marriages because of those hideous reasons already identified above. This vexed issue interests some feminist writers who might have either experienced it or have observed this social ill in their society. Through the character of Elhadj Oumar, the author holds that men are really disgusting whether they are fathers or brothers, they are all the same.

We are therefore of the view that African men, more than their counterparts from the other climes, are hostile to their women whether in love or in the other socio cultural relationships. "The African husband or lover is more prone to selfishness, pretence, self-pride and physical aggression than his wife or girl friend. Infidelity in marriage is more widespread and more open among men than women. Because of age-old male domination and prejudices, women are easily tagged as 'prostitutes' while no names are given to male prostitutes roaming around. If women ask for money, it is because the society has made them economically dependent on men. If statistics are anything to go by, there are more married men who sleep out of their homes with other women than wives doing the same thing. Any woman suspected of such act by her male partner would be lucky, if she is not beaten up or simply given a 'red card' in the marriage. As for men, they come back home without feeling threatened, suspicious or no suspicion. There are more unmarried men involved in free love than unmarried women. Many boys would not mind having two or more lovers while they raise hairs if they suspect that a rival is on the way to take one of them from them. This is what we call societal double standard in matters concerning women and men and which calls for action from responsible individuals". Okeh (1999:108). The citation is an $\mathrm{x}$-ray of women's woes especially in Africa. Some of the negative social tendencies, which pave way for feminist condemnation and, or revolt include polygamy, male infidelity, parental and extended family intrusion into the marriage of their young members and female encouragement of male maneuvers in love and marriage at the expense of their fellow women folks.

As a matter of fact, polygamy is a destructive social element against women. When relationship becomes pluralized in a marriage as it is in polygamy, the marriage which ought to be a unique union of two hearts is jeopardized. Hence, because of the questionable nature of man, feminists frown at the existence of polygamy since it is a social evil against women. Also, male infidelity, which is the genesis of polygamy, is another focus of feminism. Since men do not see anything bad or strange in taking two or more wives at a time, they are likely to be disturbed by catching fun with other women. 
It is well established that mental attitudes and behavioral tendencies guided by literature are designed in honor and favor of men folk to the debasement of woman. Jane Austen reacted thus; "Men have had every advantage of us in telling their own story. Education has been theirs in so much higher a degree; the pen has been in their hands".

As a matter of fact, many adages also demonstrate derogatory remarks on womenfolk. In many African folktales and songs, it is the women who are often used as scrape - goats or guinea pigs. For example, it is either the step-mother is a witch or the co-wife is jealous, envious or intolerant. But, the behaviors of irresponsible and arrogant husbands are never questioned or investigated. Masculine superiority or male chauvinism is again evident in our written literature. Events in African writings - novels, plays and poems remain "stomachturning", annoying and vexing especially to feminists in the way womenfolk are portrayed, decorated, painted, presented or framed-up.

\section{Conclusion}

The text, Chaque Chose En Son Temps is enhanced by the fact that the playwright, Mbuko Lynn is a product of multi-culture; an igbo by birth, French literate and works in a Hausa community. Hence, she is a multi-cultural individual. And with these make-ups, Mbuko Lynn is able to demonstrate the belief sociolinguistics holds. The relationship among language, culture and society is practically displayed. However, to allow her illiterate characters express themselves in French language, she domesticates the text by utilizing those linguistic resources which are available at her disposal. This approach notwithstanding, does not in any way affect the message content of the story. It has even enhanced the expected effects and emotional appeals which are essential to drama as a literary genre. It is also clear that literature performs certain functions which include: aesthetic function (delighting and pleasing as it appeals to the sense of beauty), didactic function (to correct man's imperfection as it teaches moral lessons), therapeutic function (healing of emotional, pathological, economic or socially connected illnesses) and linguistic function, which helps in developing the language of both the writer and readers.

\section{References}

[1] Adebayo, Aduke (2010). The Nature and Functions of Literature: The Comparatist's Perspective. An Inaugural Lecture, University of Ibadan

[2] Adeleke, Joseph A. "Feminism, Black Feminism and The Dialectics of Womanism" in Feminism and Black Women's Creative Writing. Ibadan, AMD Publishers p. 21 - 34. 1996.

[3] Adeyanju, D. (1997) "A comparative sociolinguistic Analysis of the form and functions of Taboos in English and Yoruba". An unpublished $\mathrm{PhD}$ thesis

[4] Akimajiain, A etal (2008) Linguistics: An Introduction to language and Communication. New Delhi, Prentice-Hall of India Private Ltd.

[5] Akinjobi, A (2003) “A sociolinguistic Analysis of Zulu Sofola's The Wizard of Law in Oladipo, O (ed) Ibadan Journal of Humanistic studies

[6] Akporobaro, F. B.O. (2006) Introduction to African Oral Literature. A literary-descriptive approach. Lagos, Princeton Publishing Company.

[7] Barry, P. (1995) Beginning Theory. Manchester University Press.

[8] Davies and Graves (ed) (1986) Ngambika: Studies of Women in Africa Literature, New Jersy African World Press, Davies, Joanne. 'South African and Constructive Engagement: Lesson Learned?" In Journal of Southern African Studies, Vol. 34. Routledge. 2008

[9] Faruqui, Lois. "IslamicTtraditions and the Feminist Movement: Confrontation or Co-operation" in The Islamic Quarterly xxvii, 3p. $132-139.1983$.

[10] Halliday, M.A.K. (1975) Learning how to mean Explorations in the Development of Language (Explorations in Language Study) London: Edward Arnold.

[11] Hymes, D (1964) Introduction: Towards Ethnography of Speaking in American Anthropologist Vol. 66 p. 1-34

[12] Kachiru, Y. (1992) “Culture, Style and Discourse: Expanding Noetics of English', in Kachiru, B(ed) The other. University of Illinois Press.

[13] Lopes Henri (1976): La Nouvelle Romance. Yaounde: Edition CLE.

[14] Lyons, J. (2005) Language and Linguistics: An introduction; Cambridge, Cambridge University Press

[15] Mbuko, L. (2001) Chaque Chose En Son Temps. Aba, Lynnette Publishers Creative Writing. Ibadan, AMD Publishers .1996.

[16] Ogundipe - Leslie, Molara (1994). Re-creating ourselves "African Women and Critical Transformation". Trenton, N.J. African World Press.

[17] Okeh, Peter .'A Pace-setter in Abnormal Marriage Relationships : The Case of Wali N'kama in Henri Lopes' La Nouvelle Romance in Agbasiere (ed) .1999 p. $105-132$.

[18] Olaoluwa, Senayon.'Liberation struggle, memory and freedom in Mongane Serote's Freedom Lament and Song' in African Identities. Routledge. 2012

[19] Pieterse, Cosmos and Donald Munro, (eds), (1969) Protest and Conflict in African Literature, London: H.E.B.,

[20] Rousseau J.J (1749): Discours sur I'inégalité. Vide Lagarde et Michard xvii siècle (1970). Paris; Bordas (Siecle)

[21] Schipper, Mineke. "Mother Africa on a pedestal:The male Heritage in African Literature and Criticism" in Women in Literature Today ed.Jones p. 35 - 54. London; 1982

[22] Trudgill, P. (1983) Sociolinguistics. England, Penguin books.

[23] Tyson, I (1991): Critical Theory Today. New York, Garland Publishing Press.

[24] Wardhaugh, R. (2006): An Introduction to sociolinguistics. Malden, USA. Blackwell Publishing.

[25] Welleck ET Warren, A (1971): La Théorie Littéraire. Paris, Le Seuil.

[26] Youssef, Naida H. 'Women in the Muslim world: A comparative study, (ed). Iglitzen \& Ross, Oxford: Clio Books.p.203-217. 1976. 